\title{
BMJ Global Health Improving the implementation of tobacco control policies in low-and middle-income countries: a proposed framework
}

\author{
Connie Hoe (D) , Ryan D Kennedy, Mark Spires, Stephen Tamplin, \\ Joanna E Cohen
}

To cite: Hoe C, Kennedy RD, Spires M, et al. Improving the implementation of tobacco control policies in low-and middle-income countries: a proposed framework. BMJ Global Health 2019;4:e002078. doi:10.1136/ bmjgh-2019-002078

Handling editor Seye Abimbola

Received 14 October 2019 Revised 25 November 2019 Accepted 30 November 2019

Check for updates

(C) Author(s) (or their employer(s)) 2019. Re-use permitted under CC BY-NC. No commercial re-use. See rights and permissions. Published by BMJ.

Institute for Global Tobacco Control, Johns Hopkins Bloomberg School of Public Health, Baltimore, Maryland USA

Correspondence to Dr Connie Hoe;

conniehoe@jhu.edu
As outlined in the WHO's Framework Convention on Tobacco Control (FCTC), addressing the tobacco epidemic is most effectively done through policy responses such as tobacco taxes, smoke-free public places and bans on tobacco advertising, promotion and sponsorship. ${ }^{12}$ Although tobacco control policies have been adopted across the globe, effective implementation continues to be a major challenge, particularly in low-income and middleincome countries (LMICs), ${ }^{3-7}$ where almost $80 \%$ of the world's smokers reside and where the majority of tobacco-related deaths are occurring. ${ }^{8}$ In order to fully realise the public health benefit from FCTC policies, effective implementation is required.

Policy implementation is a critical stage in the policy-making process, preceded by agenda setting, policy formulation and policy adoption. ${ }^{9}$ It can be broadly defined as the stage that focuses on 'turning policy intentions into action', ${ }^{10}$ including the activities undertaken by groups aimed at achieving the objectives set forth by the adopted policy. ${ }^{11}$ When a policy is implemented as intended by its designers, the implementation process is considered to have high fidelity, which can in turn positively affect the desired policy outcome. ${ }^{12}$

Although a number of renowned policy implementation models, frameworks and theories are available,$^{13}{ }^{14}$ none of these are sufficiently specific to tobacco control, which is complicated by the strategies and tactics of transnational tobacco companies. In fact, one of the most commonly cited barriers to tobacco control policy implementation around the world is tobacco industry interference. ${ }^{3-5}$ Existing models that do touch on the concept of partnership have focused solely on the positive aspect of engaging stakeholders
Summary box

Although tobacco control policies have been adopted across the globe, effective implementation continues to be a major challenge, particularly in low-income and middle-income countries, where almost $80 \%$ of the world's smokers reside.

- This conceptual framework illustrates the constellation of factors that have been shown to influence implementation fidelity: political commitment, institutional capacity and operational effectiveness, social climate and tobacco industry interference.

- Researchers and practitioners can use this framework to identify the points of leverage in the implementation process and contribute to actionable knowledge as well as theory development.

without taking into account opponents or disruptors. ${ }^{15}$ Moreover, the applicability of these existing frameworks and theories to LMICs requires further exploration in general, as these countries face unique challenges including a lack of resources, the need for more political support, a lack of sufficient national and local research, and limited state capacity $^{16-18}$ (defined here as the ability of states to provide public goods). ${ }^{19} \mathrm{~A}$ study examining the implementation of health warning labels, for example, found that countries with weaker state capacity were less likely to implement FCTC-compliant health warning labels. ${ }^{18}$ Public health researchers have urged for a better understanding of the process of effectively translating tobacco control policy into practice, particularly in LMICs, an understanding that encompasses the political and economic dynamics of the process. $^{20}$

The implementation framework presented here draws on existing frameworks, theories and studies, the FCTC, and experiences of 


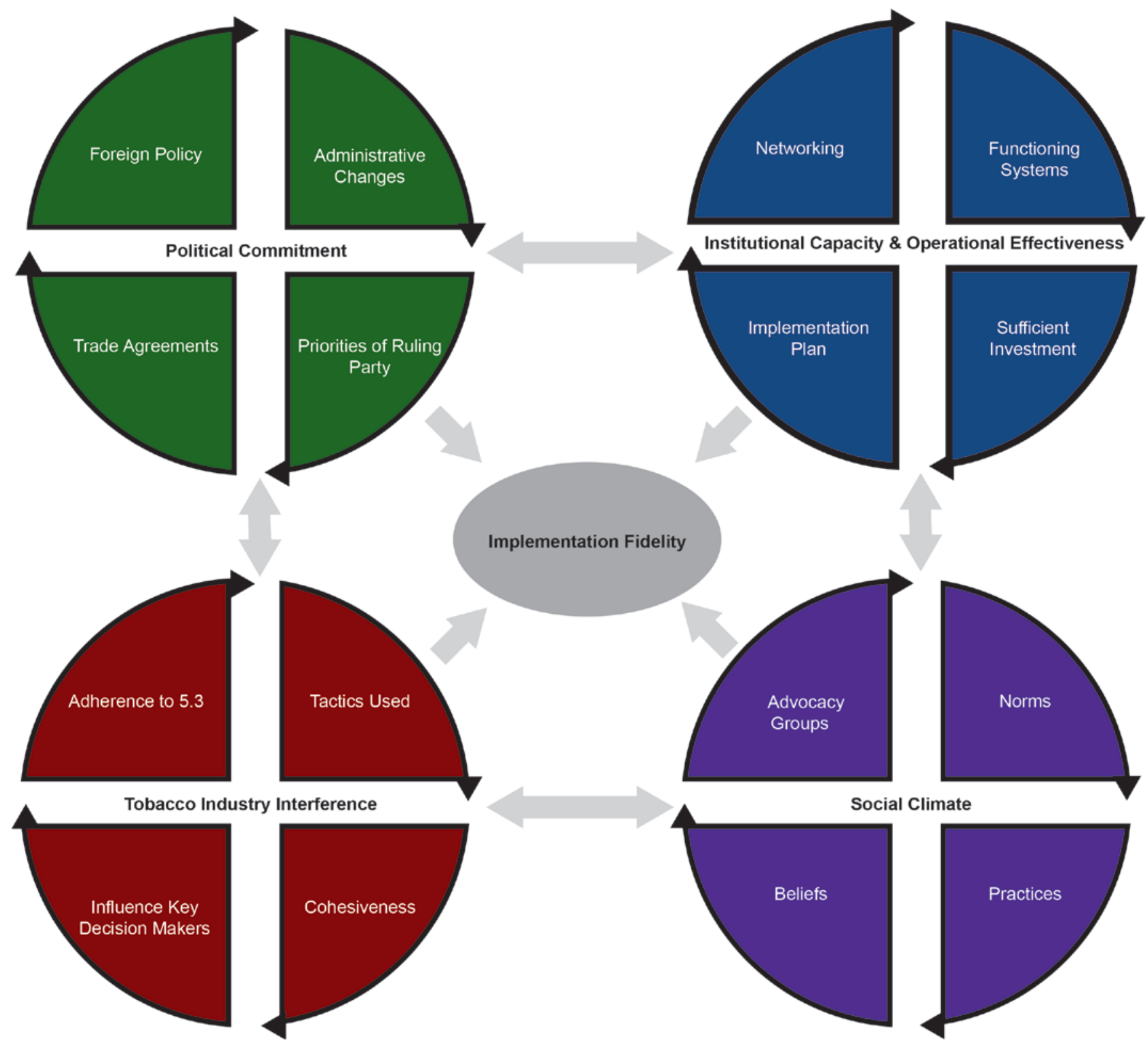

Figure 1 Framework.

experts at the Johns Hopkins Institute for Global Tobacco Control. Critical factors were identified by triangulating the aforementioned sources. As illustrated in figure 1, the framework depicts the constellation of factors that influence implementation fidelity and aims to enable countries to improve the implementation of, and compliance with, tobacco control policies. Tobacco control advocates can use this framework to better manage the policy implementation process in their countries, uncover weak areas of implementation, and leverage associated strengths and opportunities. Interventions can also be devised to target identified gaps.

The framework outlines four interacting components and related factors that have been shown to contribute to increased implementation fidelity: the first component relates to the political commitment from high-level decision makers in the country. Public policy scholars have long argued that favourable changes in government, such as turnover of key governmental actors as a result of elections and complementary priorities of the ruling party, can serve as facilitators. ${ }^{13}$ In the Philippines, for example, elections brought about new leaders who were keen on increasing tax collection efficiency and achieving universal healthcare. This created an opportunity for advocates to convince decision makers to change the existing tax structure on tobacco and alcohol products in order to generate resources for health, which ultimately enabled the successful enactment and implementation of the Republic Act 10351, otherwise known as the 'Sin Tax'. ${ }^{21}$ As tobacco control transcends national borders, a country's relationship with the rest of the world, including its trade agreements and foreign policy, 
may also influence the level of political commitment for tobacco control. Turkey's desire to gain global visibility, for example, created a political environment that was receptive to global norms and standards, facilitating the adoption of its $100 \%$ smoke-free legislation. ${ }^{22}$

The second component describes the institutional capacity and operational effectiveness of the country, state/ province or municipality. Effective implementation requires networks to be forged across sectors and among key stakeholders. Such networks can provide a critical platform for information exchange and the sharing of resources, knowledge and expertise. ${ }^{23}$ It also allows organisations to find solutions outside their traditional boundaries and address policy misalignment across sectors. ${ }^{24}$ In Zambia, for example, misalignment between the health and economic sectors served as a key barrier to the implementation of FCTC. Fostering economic growth through providing investment incentives, including for tobacco production, was central to the country's economic agenda; this is despite the high burden of tobacco use in the country and the FCTC's goal of decreasing tobacco use globally. ${ }^{24}$ Effective implementation also benefits from a functioning system, the presence of a detailed implementation plan that clearly defines roles, and responsibilities and sufficient investments to ensure adequate resources and workforce. ${ }^{14}$ This second component is consistent with Articles 5.1 and 5.2 of the FCTC that requires parties to have multisectoral national tobacco control strategies and national coordinating mechanisms.

The social climate makes up the third component: this is characterised by norms, practices and beliefs throughout the fabric of society that increases the likelihood of policy compliance. The presence of advocacy groups actively devising strategies to facilitate implementation and increase compliance is also critical. ${ }^{13}$ These groups tend to be more powerful when linked to a global tobacco control network. ${ }^{25}{ }^{26}$ In Colombia, for example, global and domestic actors worked collaboratively to implement the country's tobacco control law. Together, this transnational advocacy network ensured implementation fidelity through an array of activities including increasing public awareness, sensitising decision makers and monitoring for non-compliance. ${ }^{26}$

Finally, the fourth component refers to tobacco industry interference in the country. Tobacco companies frequently employ an array of tactics including lobbying, political campaign contributions, corporate social responsibility activities and litigation to influence the policy-making process. ${ }^{3-5}$ Implementation is likely to be even more difficult if these companies are cohesive and able to influence government officials and key decision makers. In India, for example, multinational tobacco companies, local bidi producers and smokeless tobacco companies joined forces to successfully delay the implementation of graphic health warning labels in $2007 .{ }^{27}$ It is important to note that countries like China and Japan face a unique set of challenges given that the tobacco companies are stateowned and curbing tobacco use can threaten government income. The level of a country's adherence to FCTC Article 5.3 (parties protecting policy setting and implementation from commercial and other vested interests of the tobacco industry) can also be influential. Unfortunately, findings from the 2019 Global Tobacco Industry Interference Index showed that adherence to Article 5.3 has been 'far from satisfactory' (p. 5) worldwide. ${ }^{28}$

As illustrated in figure 1, these four components interrelate. Political commitment for policy generation and effective implementation, for example, can influence the number of resources dedicated to the issue ${ }^{29}$ thereby enhancing institutional capacity and operational effectiveness. It can also have a direct impact on the population's acceptance of the policy ${ }^{30}$ and industry interference; and, committed leaders may seek to cultivate an environment that diminishes interference by adhering to FCTC Article 5.3. Likewise, enhanced institutional capacity and operational effectiveness can help foster a receptive social climate and address industry interference through both effective enforcement and public education. It also has the potential to influence political commitment through the presence of an empowered network of stakeholders and political constituents. A conducive social climate may encourage politicians to be more committed and lessen the amount of resources required to enforce the policy and fuel support to prevent tobacco industry interference. ${ }^{26}$ On the other hand, the tobacco industry can also negatively affect the other three components by lobbying politicians, interfering with enforcement efforts and disseminating false evidence to the public. ${ }^{3-5}$

There are some limitations to this framework. The relative importance of each of the components needs to be further explored. Likewise, critical questions such as how can we best leverage the different components to achieve implementation fidelity, specifically if certain components are weak also need to be answered. Despite these limitations, however, this framework draws from multiple sources of evidence and contributes to the field of health policy research in LMICs by identifying, compiling and outlining in a clear and concise manner the critical factors to be considered if the implementation of effective and reliable tobacco control policies in LMICs is to be achieved. We hope that future studies will be undertaken to test and refine this framework and to explore the applicability of this framework to other public health epidemics perpetuated by powerful industries (eg, alcohol and sugar-sweetened beverages). Such evidence will contribute to actionable knowledge and would have substantial value for both theory development and practice.

Contributors $\mathrm{CH}$ and RDK: conceived of the presented idea. $\mathrm{CH}$ : drafted the manuscript. JC: supervised the project. All authors discussed the results and contributed to the final version of the manuscript.

Funding This manuscript was supported with funding from Bloomberg Philanthropies' Bloomberg Initiative to Reduce Tobacco Use (www.bloomberg.org).

Competing interests None declared.

Patient consent for publication Not required. 
Provenance and peer review Not commissioned; externally peer reviewed.

Data availability statement № data are available.

Open access This is an open access article distributed in accordance with the Creative Commons Attribution Non Commercial (CC BY-NC 4.0) license, which permits others to distribute, remix, adapt, build upon this work non-commercially, and license their derivative works on different terms, provided the original work is properly cited, appropriate credit is given, any changes made indicated, and the use is non-commercial. See: http://creativecommons.org/licenses/by-nc/4.0/.

ORCID iDs

Connie Hoe http://orcid.org/0000-0001-8008-4010

Joanna E Cohen http://orcid.org/0000-0002-3869-3637

\section{REFERENCES}

1 WHO. WHO framework convention on tobacco control, 2017. Available: http://www.who.int/fctc/cop/about/en/

2 Cairney P, Mamudu H. The global tobacco control 'endgame': change the policy environment to implement the FCTC. J Public Health Policy 2014;35:506-17.

3 Crosbie E, Sosa P, Glantz SA. Costa Rica's implementation of the Framework Convention on Tobacco Control: overcoming decades of industry dominance. Salud Pública Mex 2016:58:62-70.

4 Gilmore AB, Fooks G, Drope J, et al. Exposing and addressing tobacco industry conduct in low-income and middle-income countries. Lancet 2015;385:1029-43.

5 Lee S, Ling PM, Glantz SA. The vector of the tobacco epidemic: tobacco industry practices in low and middle-income countries. Cancer Causes Control 2012;23:117-29.

6 WHO. WHO report on the global tobacco epidemic, 2019. Available: https://www.who.int/tobacco/global_report/en/

7 WHO. 2018 global progress report on the implementation of the WHO framework convention on tobacco control, 2019. Available: https://www.who.int/fctc/reporting/WHO-FCTC-2018_global_ progress_report.pdf?ua $=1$

8 WHO. Tobacco, 2017. Available: http://www.who.int/mediacentre/ factsheets/fs339/en/

9 Anderson J. Public policy-making. Boston: Houghton Mifflin Company, 2003.

10 John P. Analysing Public Policy. 1998. London: Pinter, 1998.

11 Van Meter D, Van Horn CE. The policy implementation process: a conceptual framework. Administration and Society 1975;6:445-88.

12 Carroll C, Patterson M, Wood S, et al. A conceptual framework for implementation fidelity. Implement Sci 2007;2.

13 Sabatier P, Weible C. The advocacy coalition framework: innovations and clarifications. 2nd Ed. PA Sabatier. Boulder: Westview Press, 2007: 189-220.

14 Lipsky M. Street-Level Bureaucracy: Dilemmas of the Individual in Public Service. New York: Russell Sage Foundation, 2010.
15 Tabak RG, Khoong EC, Chambers DA, et al. Bridging research and practice: models for dissemination and implementation research. American Journal of Preventive Medicine 2012;43:337-50.

16 Munzer A. The WHO FCTC: the challenge of implementation. Lancet Respiratory Medicine 2013;1:182-4.

17 Leischow SJ, Ayo-Yusuf O, Backinger CL. Converging research needs across framework convention on tobacco control articles: making research relevant to global tobacco control practice and policy. Nicotine Tob Res 2013;15:761-6.

18 Hiilamo H, Glantz SA. Implementation of effective cigarette health warning labels among low and middle income countries: state capacity, path-dependency and tobacco industry activity. Soc Sci Med 2015;124:241-5.

19 Ottervik M. Conceptualizing and measuring state capacity: testing the validity of tax compliance as a measure of state capacity, 2013. Available: https://qog.pol.gu.se/digitalAssets/1468/1468814_2013_ 20 ottervik.pdf

20 Bump JB, Reich MR. Political economy analysis for tobacco control in low- and middle-income countries. Health Policy Plan 2013;28:123-33.

21 Madore A, Rosenberg J, Weintraub R. "Sin Taxes" and Health Financing in the Philippines. Boston, MA: Harvard Business Publishing, 2015

22 Hoe C, Rodriguez DC, Üzümcüoğlu Y, et al. "Quitting like a Turk:" How political priority developed for tobacco control in Turkey. Soc Sci Med 2016;165:36-45.

23 Roussos ST, Fawcett SB. A review of collaborative partnerships as a strategy for improving community health. Annu Rev Public Health 2000;21:369-402.

24 Lencucha R, Drope J, Labonte R, et al. Investment incentives and the implementation of the framework convention on tobacco control: evidence from Zambia. Tob Control 2016;25:483-7.

25 Keck M, Sikkink K, Borders AB. Ithaca. NY: Cornell University Press, 1998.

26 Uang R, Crosbie E, Glantz SA. Tobacco control law implementation in a middle-income country: transnational tobacco control network overcoming tobacco industry opposition in Colombia. Glob Public Health 2018;13:1050-64.

27 Sankaran S, Hiilamo H, Glantz SA. Implementation of graphic health warning labels on tobacco products in India: the interplay between the cigarette and the bidi industries. Tob Control 2015;24:547-55.

28 Stopping Tobacco Organization \& Products. Global tobacco industry interference index, 2019. Available: https://ggtc.world/ dmdocuments/GlobalTIIIndex_Report_2019.pdf

29 Shiffman J. Generating political priority for maternal mortality reduction in 5 developing countries. Am J Public Health 2007:97:796-803.

30 Kaufman MR, Merritt AP, Rimbatmaja R, et al. 'Excuse me, sir. Please don't smoke here'. A qualitative study of social enforcement of smoke-free policies in Indonesia. Health Policy Plan 2015;30:995-1002. 